NGTT Deel 54, Nommers 3 \& 4, September en Desember 2013

Cloete, Daan ${ }^{1}$

University of the Western Cape

\title{
Galatians 2:15-21 and the Belhar Confession (1986) in dialogue
}

\begin{abstract}
This article brings Gal 2: 15-21 into dialogue with the Confession of Belhar (1986). It starts off with the issue of the formation of confessions in Early Christianity and asks whether there could be a confession basic to or in the making in the Galatians passage. The Confession of Belhar (1986) is structured around three concepts, namely, unity, reconciliation and justice within the South African context of the churches disunity with all its social consequences. Galatians reflects a critical and decisive period in the history of the Early Christianity as it struggles with the issue of justification. In this pericope Paul focuses on Justification by faith, but supports it with other concepts like grace, equality/unity and freedom. While these sets of concepts do not correspond with one another, they both reflect a crucial period of transformation in the history of the church.
\end{abstract}

The issue of justification in Galatians 2:15-21 forms the focus of this article. In this passage Paul counters justification by the works of the law with justification by faith. The passage is also read in dialogue with the Belhar Confession (1986). Analogously, this confession stands antithetical to the theological justification of apartheid. It is generally recognised that Dirkie Smit has made a significant contribution to the Confession. ${ }^{2}$

\section{TEXT-TECHNICAL AND LITERARY ANALYSIS}

The majority of scholars are of the opinion that not all of Galatians 2:15-21 is a verbatim rendering of Paul's strong criticism of Peter and Barnabas regarding their conduct in Antioch. That 2:14b, which serves as an introduction, is direct speech is not disputed. However, what follows appears to be more of a pre meditated formulation than a spontaneous reaction. This raises questions about the origin and character of these verses: Could it be an extract from an existing statement, perhaps drawn up after the Jerusalem meeting as a response to an issue that seems to have become a major problem in many of the Christian communities at the time ${ }^{3}$ Or is it a carefully composed summary of Paul's reprimand drawn up by Paul himself, perhaps in consultation with his fellow

1 G. D. (Daan) Cloete is Professor Emeritus of New Testament in the Department of Religion and Theology at the University of the Western Cape, South Africa.

2 Dirkie Smit was on the drafting commission of the confession appointed by the Dutch Reformed Church Synod of 1982.

3 Acts 15 indicates that the place of the law within early Christianity was such a controversial issue that it necessitated the meeting of the church leadership in Jerusalem. Jerusalem features much in the Letter to Galatians $(1: 1718 ; 2: 1 ; 4: 25-26)$ and it could mean that the meeting was forward in Paul's mind when he wrote it. Paul also deals with the issue quite extensively in Rom. 35 and also in 2 Cor. 3:4-18 (cf. 2 Cor. $4: 13 ; 5: 7)$. Gal. 2:1-10 suggests some general agreement reached at the Jerusalem meeting because, when Paul met with those who were regarded as the pillars in the church, they did not dispute or correct him. 
NGTT: Oopbron - http://ngtt.journals.ac.za

workers (1:2), to be used in a broader context in order to address a problem that threatened the church in its infancy?

New Testament authors regularly quoted the primitive Christian tradition that was primarily orally transmitted traditions to support their messages. By using certain text critical techniques and literary analyses, it has become possible to identify some of these traditional creeds, confessions, hymns, statements, et cetera. Some typical characteristics that could suggest the presence of such underlying traditional material from early Christian texts have been identified. Cullmann's initial work (1949) regarding this is well known. More expanded and thorough is the work of Neufeld. ${ }^{4}$ Applying some of the features that he and others had identified, the possibility that a statement of a confessional nature could be the foundation of Galatians 2:15-21 will be explored.

After a linguistic study to determine criteria to detect the homologia in early Christian literature, Neufeld applied these to the Pauline corpus. Some of the criteria include "the homologeinhomologia word group". He found that

[O]ther verbs of a kerugmatic, didactic, or confessional nature also provide certain clues pointing to the homologia. In addition, syntactical considerations may be indicative of formulary material, such as the use of oti, the double accusative, and the infinitive to express a statement which is quoted directly or indirectly. In other passages a participial construction or the use of relative clauses may introduce "creedal" material. The total evidence which is thus revealed in the letters must be evaluated in an effort to precipitate the form or forms which rightly may be called the Pauline homologia (Neufield 1963:42).

Neufeld then identifies forms of homologia in Paul, and after some detail analyses of specific Pauline texts, concludes:

[T] he letters of Paul contain basically three forms or patterns which appear to be related to the primitive homologia: the simple formula, Kurios Isous, the two article formula which refers to Jesus as Lord and God as Father, and an antithetical pattern, appearing in several forms, in which a contrast is drawn between the earthly career of Jesus and the new position granted him in the resurrection. The evidence clearly indicates that the basic homologia in the Pauline epistles is the simple formula Kurios Isous. The precise relationship of the two article formula and the antithetical pattern to this homologia is less certain (1963:51).

If one now considers these clues or indicators with regard to Galatians 2:15-21 in order to determine whether it has any features of an early confession, ${ }^{5}$ the following is of interest:

- The use of oti as an indication of a possible "quotation" from another source is absent.

- $\quad$ The word homologia does not appear but the word pistis - which, according to Neufeld (1963:32), is related to it and suggests a body of faith - does. It is probably the most central concept in the pericope, appearing both as a noun and a verb $(2: 16,20$; cf. 1:23).

4 Neufeld, however, does not identify Gal. 2:15-21 as a possible early Christian confession.

5 Gal. 4:4 ("God set his own Son, born of a woman, born under the law", et cetera.) indicates that Paul was not ignorant of formulary patterns. 
NGTT Deel 54, Nommers 3 \& 4, September en Desember 2013

- $\quad$ "Jesus is Lord" in this formula form does not appear as such within this particular passage. However, Paul uses it at the beginning $(1: 3)$ and end $(6: 14,18)$ of the Letter thereby indicating his acceptance of it as a basic confession from tradition. He does use the titles Jesus Christ and Christ Jesus in the 2:16 and many times more in the Letter. Interestingly, Paul frequently uses the adjective Christ as a proper noun independent of Jesus inside $(2: 16,17,20$, and 21$)$ and outside of the passage that could point to a traditional formula to emphasise that Jesus is the only Christ. ${ }^{6}$ These uses together suggest that Paul was not only conscious of but also made use of the Christological titles from tradition in the Letter and in the passage.

- $\quad$ Similarly, Jesus Christ and Son of God also appear in the statement - not in a formulary combination, but separately. Jesus Christ was already discussed above. The titles Son of God (2:20) and God do appear $(2: 19,21)$ - also many times elsewhere. They are not used in an antithetical manner to describe the earthly and heavenly positions of Jesus, but separately. However, the resurrection of Jesus is expressed in 1:1, and the earthly. In 4:4 with regard to the incarnate Son of God. This indicates Paul's dependence on both.

- Paul does use a different form of the earthly/heavenly antithetical pattern in this statement when he focuses on the crucifixion of Jesus, using it in a way that it includes his resurrection. This also comes to expression in the life of the believer (2:20). On the cross the latter dies with the (earthly) Jesus and then lives with the (resurrected) Christ who lives in him or her (cf. 4:19).

- $\quad$ Striking is the binary pattern in the passage, as indicated by, among others: i) Jews by birth/Gentiles as sinners (2:15); ii) works of the law/faith in Christ (2:16); iii) building up/ pulling down (2:18); iv) died for the law/live for God (2:19); and v) my life/the life which Christ lives in me (2:20). This pattern is consistent with the rest of the Letter. It shows that this thought pattern is characteristic of Paul. They function to draw very clear boundaries (cf. Neyrey 1990:190-191).

Characteristic of the apartheid policy was not only that it wanted to drawgeographicalboundaries as expressed in the Homelands and Group Areas Acts, but in doing so, it also wanted to create separation along racial, social and religious lines, even amongst Christians. These boundaries were symbolic and caused mental and spiritual alienation amongst people, focusing not on what people had in common but on what separated them.

- Similarly striking is the accumulation of prepositions in the passage, such as: "by birth" (2:15);"by the works of the law, through faith in/of Christ Jesus" (2:16); "in/on Christ"','against the law" (2:17); "through the law to the law", "for God" (2:19); "with Christ", "by faith in the Son of God", "for me" (2:20); "of God", "by law", "for nothing" (2:20). With Paul the use of these prepositions always has a particular significance in that they incorporate the believer into the totality of Christ's work of salvation, in particular into his death and resurrection. This adds to the confessional possibility of this section.

6 Neufeld (1963:3441) discusses the "Confessions of Faith in Judaism" and argues that "the confession which served more precisely as Judaism's homologia was the Shema"(35). It was recited in the temple and the synagogue by the congregation as a whole. It was used over and against the Gentile polytheistic religions to emphasise Judaism's monotheism. Perhaps this kind of thinking could have influenced Paul in his emphasis on Jesus being the (only) Christ. Also in this regard Dunn (1993:41): "[T]he complete identification of Jesus as the 'Christ' of Jewish hope lies beyond and must certainly have been the reason for it becoming a second identifying name for Jesus." 
NGTT: Oopbron - http://ngtt.journals.ac.za

Betz (1979:26-28), in his famous commentary based on a rhetorical reading of Galatians, makes some interesting remarks in this regard. In his introduction to the commentary, he deals with "Traditions and Doctrinal Presuppositions" and indicates that Paul used them to build his argument. With regard to Galatians 2:15-21, these presuppositions include: i) references to Christ (2:20); ii) Christological titles (2:20); iii) doctrinal material from Jewish Christianity such as the doctrine of justification by faith (2:1516); iv) the citation of an antiPauline polemic (2:17); v) doctrinal material from Paul's own theology including Pharisaic doctrines once held and now rejected, for example, the doctrine of justification (2:21c); vi) Paul's definition of his gospel, including the doctrine of justification by faith (2:15 -16); definitions of Christian existence such as freedom from the Torah (2:19a), a life in faith (2:20b); guidelines for Christian existence in the future, for example, rebuttal against opponents $(2: 17-18,21)$. Paul also includes a number of abbreviations or expressions of theological doctrines that probably have their origins in oral transmission of Paul's theology. These include: "out of the works of the law" $(2: 16) ;$ "through the law" $(2: 19,21)$; "through the faith" (2:16); "out of faith" (2:16); "in faith" (2:20); "in the flesh" (2:20); in Christ" (2:17); and "gave himself over" (2:20). While all these do not necessarily argue for a single source that Paul quoted, its collective presence in this passage does show that he depended much on traditional and doctrinal presuppositions for its composition.

Structurally the passage consists of two sections indicated by the use of the pronouns, the plural "we" and the singular "I", respectively. The "we" section is found in 2:15-17, and the "I" section in 2:18-21. Within each section the use of both the "we" and the "I" differs. Sometimes it is used emphatically ("we", 2:15; "I", 2:20) and at other times rhetorically ("we", 2:17; "I", 2:18). In the "we" section the passage starts with a statement about a perception that probably existed (v. 19) amongst Jews in general to which the "we" in verse 16, seemingly referring to Christians, is a response. It then continues with a rhetorical question to which the "I" section (1821) is now the response. The rhetorical "I" in 1819 probably alludes to Jewish Christians, while the emphatic "I" in 21 seems to express Paul's personal conviction. ${ }^{7}$ The use of both these pronouns adds to the confessional character of the passage. ${ }^{8}$

From these more technical and linguistic aspects of the passage it may be concluded that the passage

- $\quad$ does not seem to be a verbatim reflection of the reaction started by Paul in verse $14 \mathrm{~b}$ but rather a compact statement about the issue under discussion;

- does not in total seem to be an extract or quotation from an existing document from Christian tradition; rather,

- $\quad$ it probably is a composition based on early Christian and Pauline traditions

- $\quad$ and doctrines drew up by Paul perhaps in consultation with his fellow workers as a response to a persistent problem that was experienced in primitive Christianity with regard to content of the faith in Jesus Christ.

Therefore, while it cannot be identified as a confession in the true sense, the passage's

\footnotetext{
7 For a detailed discussion of the structure cf. Grossouw 1974:99.

8 Both formats appear in formal confessions. The first person singular usually emphasises personal conviction, for example, the Apostle's Creed, while the first personal plural underlines the universal acceptance, for example, the Heidelberg Catechism.
} 
NGTT Deel 54, Nommers $3 \& 4$, September en Desember 2013

structural compactness and meaningful, mature theological argument gives it a confessional

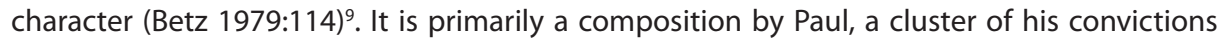
built upon and resting on long established and traditionally coined truths. It reflects the contours of a confession but may best be described as a propositional statement or a creedal type of theological reflection.

There is a difference between creeds and confessions formulated in and outside of the New Testament. The former served as the foundation stones of primitive Christianity, shaping the unfolding Jesus movement and these were canonised as part of Scripture. Those formulated outside of Scripture were really responses to it in situations of crisis that threatened the faith of the church. Although confessions also originated in post New Testament times - for example, the Apostle's Creed - a real proliferation of confessions occurred during and after the Reformation. In more recent times another spurt of confessions appeared as the processes of democratisation and liberation developed across the world, throwing up many issues that the church had to respond to.

The Belhar Confession (1986) is such a confession of recent times. It originated in a context in which racism was legitimised by a political ideology and sanctioned by Scripture. Belhar came from the DRMC. It stands in the Reformed tradition, which also takes its basic point of departure from justification by faith. This church has three traditional confessions, all focused on specific issues that were faith threatening around the time of the Reformation. The issue of racism is not explicitly addressed by these three since it was not the focus at the time of their formulation. However, Belhar does, as it was the burning issue of its time.

\section{THEOLOGICAL SIGNIFICANCE}

The passage is presented as integral part of the content of Galatians. Although it is embedded in the Letter and cannot be dealt with in total isolation from it, it has a distinct identity and function. As the central affirmation of the Letter, it forms the hinge around which the Letter was structured, and marks the transition between its two major sections. The historical autobiographical section (1:1 to $2: 21$ ), contains a build-up of events that took place prior to and including the incident in Antioch, all of which had a bearing on developments in Galatia. It brings the section to a culminant close. At the same time, this passage serves as an introduction to the next section (3:16:18). It forms the theoretical doctrinal basis for its analysis and exposition. In this section, Paul gives Scriptural support to his stance in 2:15-21 and spells out the implications of his gospel. It is Paul's résumé about the truth of the gospel, as he puts it (2:5), which he then contextualises, unpacks and elaborates on (cf. Betz 1979:114).

Belhar is accompanied by a separate letter which is presented as of equal importance as the Confession itself. It gives the background and context in which the confession originated and some hermeneutical indicators of how it should be read (cf. Cloete \& Smit, (Eds) 1984).

In the broader context of the passage (1:62:14), Paul argues that the only source of his ministry is God's revelation to him, without consultation of any "flesh and blood" (1:16). It seems that his Damascus experience included a) his conversion, b) his calling and authorisation as apostle,

9 In Betz's rhetorical analysis of the Letter this passage is called the proposition, which is usually placed between the narratio and the probatio. Here "[t]he propositio is extremely concise and consists largely of dogmatic abbreviations, that is, formulaic summaries of doctrines" (1979:114). 
NGTT: Oopbron - http://ngtt.journals.ac.za

c) his mission to the Gentiles and d) the content of what he was to proclaim. Galatians 2:15-21 could also be seen as a reflection of the content of that revelation - to Paul the truth of the gospel. It has previously been argued that what appears to be is a verbatim rebuke of Peter and Barnabas by Paul with regard to their behaviour in Antioch on closure scrutiny suggests an intense engagement with and deep thought on the incident. Paul's other letters support the idea of serious reflection on the issue for a broader purpose. ${ }^{10}$ The rhetorical use of "we" in 2:17 also indicates that Paul no longer had only Peter and Barnabas in view but a much broader audience - even the universal audience of believers.

The structure of the passage is dense and complex. It concerns a dispute between two Christian groups and is constituted by the arguments of Paul's opponents in Galatia and his responses to them. Apologetic and polemic elements are all integrated and presented in a discussion or so called diatribe style. ${ }^{11}$ Structurally the passage can be subdivided into

- $\quad$ verses 15-16 which emphatically states that justification is by faith in Christ and not by works of the law. Verse 15 contains the thesis regarding the general perception of Jews about themselves and about the Gentiles which is defeated in verse 16's quotation from Psalm 143:2.

- Verses 17-18 rhetorically sketch, in a hypothetical manner, the disputed areas. In verse 17 Paul indicates the consequence when faith in Christ is used in combination with the works of the law. According to verse 18, It boils down to building up again what has already been broken down. This makes one a transgressor. This logic could also have the consequence that Christ be declared a servant of sin. As far as Paul is concerned, through his faith in Christ, he has died for the law to live for God.

- Verses 19-20, presented in the emphatic "I" style, are presented as a personal testimony by Paul about some of the theological issues under discussion. He now introduces another binary combination, faith and flesh, to spell out what it means for him to live, justified by faith but still in the age of the flesh: It is a life of faith in the crucified Christ who, as the Son of God, gave himself in love for us.

- Verse 21 concludes the pericope in rhetorical "I" style. Here Paul seems to deny a particular accusation against him with regard to God's grace. He evaluates the two positions on justification again, particularly against the background of the death of Christ on the cross. To Paul the crucifixion is the demonstration of God's grace.

The obvious, central theme of the statement - and, for that matter, of the Letter - is justification by faith. To Paul this is the truth of the gospel $(2: 5,15)^{12}$, as supported by his other writings. "Justification" is a term that comes from the Pharisaic religious context in which Paul grew up. This system required that one had to meet certain Jewish legal obligations (works of the law) in order be justification by God. Paul, by his own testimony (Phil. 3:56), was a zealous and exemplary exponent of this view (Acts 9:12). However, in the light of his Christ

10 This does not mean that Galatians has to be read in a very abstract and theoretical manner. According to Beker (1980:28), Paul made use of "contextual interpretation". By this Beker means "that the intent and thrust of Paul's thought is inseparable from the specific situation that evokes it."

11 Betz (1979:114) comments as follows: "This passage is a summary of the doctrine of justification by faith. It is thoroughly Pauline, but Paul's claim that he shares this doctrine with Jewish Christians should be taken seriously."

12 Confessions and creeds always indicate decisive moments in the history of the church, that is, crisis situations that demand taking a position because the truth of the gospel is at stake. 
NGTT Deel 54, Nommers $3 \& 4$, September en Desember 2013

experience and God's revelation to him, Paul came to acknowledge the futility of the system. Given Paul's own agonising struggle with the issue after his Damascus experience, he surely had some understanding for the struggle of the Jewish Christians. However, it was clear to him that a radical break was the only way forward.

The impression seems that Paul turned against the law completely. However, his new position of faith created a new framework for him. He now saw things from a more apocalyptic perspective: there are two dispensations, two worlds and two covenants, namely the old and the new. The old world, which still prevails in some measure, is evil (1:4). Weare still slaves of this old world and we entertain its first principles (4:3), including the works of the law. When crucified with Christ, the old world is also crucified for us. Once freed from it (3:13), the "new creation" (6:15), the "Israel of God" (6:16), the "kingdom of God"(5:21) has dawned for us.

In this new context there is also a new understanding of the law as the law of love. In one sense this understanding is not totally new - it was already given to Israel in Leviticus 19:18. This means that Paul's understanding is in continuity with the intention of the Torah. In another sense, Paul probably also wanted to indicate that his understanding of the law is in accordance with Jesus' teaching regarding the law. That is why it can be called the law of Christ (6:2) with a focus on relationships of love and reconciliation as embodied in the life of Christ. These relationships go beyond the narrow and particularistic interests of Israel. It finds expression in "works of love" (5:6), and in "carrying one another's burdens" (6:2). It also means allowing the Spirit of Christ to develop a value system and love virtues not in a legalistic way, but as its fruit (5:22). Therefore, the law was not given to merit righteousness but rather to live righteously.

To those commissioned to draft Belhar it was not merely an intellectual exercise. They were commissioned also because the theological justification of separate development was an existential issue to them. Some, like Paul, grew up with and were educated in the teachings of the doctrines of the ideology of apartheid and its theological justification. Others could have been so conditioned that they may have become blind to the deep rooted discriminatory character and racial prejudices of the ideology. It is clear that Belhar came into being after a long history of spiritual agony both within the church and on the side of the drafters. The latter not only articulated what the church struggled with and the country suffered under, but in Belhar they expressed their own convictions and their solidarity with those who were the first victims. To them it also meant a radical shift.

\section{DeEPER STRuctural LEVEL}

While justification by faith is the central theme of the passage, there are some concepts in it and in the broader context of the Letter that function at a deeper structural level that inform the central theme and bring out its various dimensions and facets. These half hidden concepts give profound meaning to "Paul's gospel" of justification by faith.

1. Justification by faith and grace. Grace brackets the historical autobiographical part 1:6 and 2:21) as well as the whole Letter (1:6 and 6:18). It also marks its strategic moments, for example, $2: 21$ and 5:4.

In 1:6 and 2:21 Paul focuses on God's calling, both to the Galatians and to him personally. As these callings were the result of God's grace, not heeding them meant rejecting God's grace and rendering Jesus' resurrection meaningless. In 5:4 Paul points out that to want to add 
NGTT: Oopbron - http://ngtt.journals.ac.za

works of the law to faith in Christ actually means severing the relationship with Christ and falling from grace. Paul's typical benediction (6:18) breathes the expectation that the Galatians would return to embrace God's grace once more to faith in Christ actually means severing the relationship with Christ and falling from grace. Paul's typical benediction (6:18) breathes the expectation that the Galatians would return to embrace God's grace once more.

This indicates that underlying the statement in 2:15-21 as well as in the whole Letter is the concept of grace. By it, Paul means the unconditioned, undeserved all inclusive act of justification and salvation by God through Jesus Christ, his Son. The story of God's grace is told in the story of Jesus Christ. ${ }^{13} \mathrm{He}$ is the embodiment of God's grace. Therefore, it is a concept that stands in apposition to justification by faith and in opposition to justification by works of the law. ${ }^{14}$ It is clear that faith and grace are two sides of the same coin: both are gifts of God.

Belhar is structured around three concepts: unity, reconciliation and righteousness. Grace is not one of its central concepts, nor is it even mentioned in Belhar. However, there is no doubt that Belhar also takes as its point of departure God's grace as expressed in the story of Christ. Its first article clearly states: "We believe in the Triune God, Father, Son and Holy Spirit, who gathers, protects, and cares for his Church by his Word and his Spirit, as he has done since the beginning of the world and will do to the end." The Confession speaks of unity of the church as a "gift", of the church as "thepossession of God" and it ends with the oldest traditional confession, "Jesus is Lord". These are all indications that consciousness of God's grace as told in the story of Jesus Christ serves as an a priori to the reading and understanding of Belhar.

2. Justification by faith and equality/unity. Paul starts his statement with probably the contemporary Jewish viewpoint about themselves in relation to the Gentiles: "We ourselves are Jews by birth, not Gentiles and sinners" (2:15). This statement expresses the Jewish understanding of the basic difference between Jews and Gentiles as contained in their law. Because they have been entrusted with the law, they regard their position as already justified and that of Gentiles as sinners by definition. Some Jewish Christians now wanted to carry over into the Christian community this understanding by making the law obligatory for Gentile Christians. They found that faith in Jesus Christ is insufficient for justification and wanted to complement it by the works of the law. Given the broader political context in which Jews found themselves, a position of oppressed inferiority, there were clear socio religious and nationalistic motifs of proselytising by Jewish Christians, as suggested by the demand for circumcision. ${ }^{15}$ Against the background of the Antioch incident, it also has undertones of racism. ${ }^{16}$ In other words, Jewish Christians, for reasons of Jewish self-interest, wanted to carry over this basic human inequality contained in the law into the Christian faith.

Paul challenges this inherent inequality by stating that no person will be justified by the

13 Hays $(1983: 56,21)$ has argued that "the framework of Paul's thought is constituted neither by a system of doctrines nor by his personal experience but by a 'sacred story', a narrative structure and that the story provides the foundational substructure upon which Paul's argumentation is constructed, and that without awareness of the story the theological discourse of Galatians is unintelligible."

14 Bruce (1982:80) states: "Grace and law are mutually exclusive as means of justification (cf. 5:4)."

15 Circumcisions, dietary prescriptions, et cetera, were primarily identity markers for the Jews.

16 Dunn (1993:78): "It was precisely this sense of distinctiveness and thus also of set apartness which obviously lay behind the attitude of the James group ... In typical Jewish thought to do the works of the law would mean maintaining a social life as far as practically possible apart from the Gentiles." 
NGTT Deel 54, Nommers $3 \& 4$, September en Desember 2013

works of the law. He argues for the essential equality of both Jews and Gentiles at two levels: All are sinners and all can be justified, but only by faith in Christ. To Paul justification by faith is the great equaliser and sole condition for all humanity to be saved.

In most of chapter 3, Paul justifies his position with reference to the Torah - probably to counter the Old Testament use by his opponents. He does so by discussing the law in its relationship to the covenant with Abraham. To him the most significant aspect of that covenant is God's promise given to Abraham (Genesis 15) that the latter's descendants (seed) will be as many as the sand of the sea and the stars in heaven. This was to Paul an indication that the Gentiles were included in the promise. Abraham accepted that promise by an act of faith and on the basis of that faith he was declared righteous and became the father of all believers. Two things become clear: First, justification by faith has its roots in the faith acceptance of God's promise by Abraham. Second, the equality of all people is expressed in the promise.

Circumcision was given afterwards merely as a sign and identity marker (Genesis 17), as was the law, which was given to Israel 430 years later together with the special calling to sustain the promise. The law was to serve as a pedagogue to educate towards the fulfilment of the promise. However, Israel abused the law in order to serve their exclusivist national interests and racial sentiments. Instead of maintaining the faith character of the promise they gave it a works character via the law and used the latter as an identity marker for themselves. This meant that for a non-Jew, justification could only be reached by becoming a Jew.

Paul presents Abraham's unhesitant embrace ofGod's promise as an example offaith in action. But to Paul there is also a deeper fulfilment of the promise as expressed in the singular use of the word "seed" (3:16). This saw its fulfilment in Christ. Depending on the latter, there is further fulfilment of the promise as expressed in the plural use of the word (seed) (3:29). This fulfilment refers to all those, irrespective of their race, who follow Abraham's example by simply believing. However, their faith now is in Jesus Christ through whom they also become children of God. Because all of this is related to the original intention of the promise to Abraham, they can also be regarded as children of Abraham and heirs of the promise.

Subsequently, Paul spells out the extent of all of this: Justification by faith has socio ethnic, socioeconomic and gender related consequences (3:26-29). All discrimination, oppression and inequality are exposed and should be abolished. This justification emphasises the liberating and equalizing effect of faith in Jesus Christ on all spheres of life and it states emphatically that all people are one in Christ. Starting from the premise that all humanity is equal in sin, Paul declares that through justification by faith all humanity is one and should, therefore, become what it is in Christ.

With this passage Paul wanted to address the fundamental inequality that prevailed in his society, and that was justified by the religious practices of the time. The exposure and uprooting of these evils could only happen through justification by faith in Christ.

Both Paul and Belhar take justification by faith as their points of departure. Both accepted church unity but Belhar fights the mystical interpretation of the church that seeks to avoid any cultural and racial integration. Paul fights the idea of different ways of justification for different cultures. Belhar argues that once justification by faith has been achieved, racial and cultural separation in the church become irrelevant. Paul rejects the extension of the Jewish prejudices and racial attitudes towards Gentiles into the church, while Belhar explicitly and implicitly rejects any doctrines that "absolutise either natural diversity or the sinful separation of people and the 
NGTT: Oopbron - http://ngtt.journals.ac.za

forced separation of people on the grounds of race and colour". It also rejects "any ideology which would legitimate forms of injustice and any doctrine which is unwilling to resist such an ideology in the name of the gospel."

3. Justification by faith and freedom. The concept of freedom is also merely implied in the passage. In 2:4 Paul talks about "our freedom that we have in Christ Jesus". In context it refers to the faith situation of Paul and Titus but it surely applies to all who are in Christ. Behind the concept of freedom is the slave/free person imagery, which features extensively in the Letter. In 3:13 it alludes to the ransom paid to free a slave. The law is a curse that hangs over us and from which we have to be freed. It features as the background to 3:2425 with regard to the pedagogue, who is really a slave responsible for the child's education. In 3:28 it is indicated as one of the barriers that need to be broken down.

Faith and freedom is also the dominant theme in the allegory in Galatians 4:205:15. (cf. 2:17). The two sons of Abraham represent the roots of the freeing promise versus that of the enslaving law. They are the sons of Hagar, the slave woman, symbolising the law, and the other son born of the free woman Sarah, symbolising faith. These two women also represent two covenants. Mount Sinai, the place where the law was given to Moses, bore slave children. By implication, the other covenant came into being through the promise to Abraham who, by Sarah, was the father of a free child. This made Isaac a child of the promise and, by implication, Ishmael a child of the law. The allegory is then extended to Jerusalem. Jerusalem of that time is related to Sinai, representing the law. The other Jerusalem is free and, like a mother, embraces all those who are born in faith. It is clear that for Paul the law has an enslaving character while faith in Christ has a liberating character.

Paul takes the issue of enslavement versus freedom further by reminding the Galatians of their own socio religious background before he brought them the gospel. They were also enslaved by the gods they worshipped, and by the principalities by which they lived. To Paul their situation at the time seemed analogous to the workstheoflawsituation of the Jews (cf. Patte 1983:72). The gospel of faith in Jesus Christ brought the Galatians freedom. By adding the works of the law to their faith they would have reverted to their original enslaved state.

The significance of justification by faith for Paul is that it brings freedom. It is an all-inclusive freedom from all kinds ofidolatrous graceless powers or other manifestations ofenslavement.

The concept of freedom is again not one of the concepts around which Belhar was drafted. Belhar does emphasise that church unity "can be established only in freedom and not under constraint". It also uses the concept when it deals with the issue of justice and peace among people. It states that God "frees the prisoner". Paragraph 4 of the Accompanying Letter argues that Belhar is a proclamation "against a false doctrine and an ideological distortion which threatens the gospel itself in our church and in our country." It continues:

"We do not doubt the Christian faith of many such people, their sincerity, honour, integrity, and good intentions and their in many ways estimable practice and conduct. However, it is precisely because we know the power of deception that we know that we are not liberated by the s eriousness, sincerity, or intensity of our certainties, but only by the truth in the Son. Our church and our land have an intense need of such liberation."

This describes the background against which Belhar was born, namely one of oppression and 
NGTT Deel 54, Nommers $3 \& 4$, September en Desember 2013

enslavement, where the political dispensation was upheld by laws that were oppressive and discriminatory toward the majority of people of the country. It is also clear that Belhar yearns for an all-inclusive freedom. In paragraph 4 the Accompanying Letter (cf. Cloete \& Smit, (Eds) 1984) concludes:

"We pray that our brothers and sisters throughout the Dutch Reformed church family, but also outside it, will want to make this new beginning with us, so that we can be free together and together may walk the road of reconciliation and justice."

\section{Conclusion}

In conclusion, the basic thrust of this passage seems to be the issue of transformation. By introducing the works of the law as additional requirement for justification to that of faith in Christ, Paul's opponents were in fact promoting change. In the light of the Christ event they were prepared to make adjustments to the existing Jewish scheme of salvation, but also to maintain its basic structure. They limited themselves to the improvement of the existing structure.

However, in Paul's understanding, the gospel intended to bring about total transformation. This meant abandoning all human effort to obtain justification and embracing in faith the justification graciously offered by God through Jesus Christ. From this position, fundamental changes could now be made in the life of the person and in society by the transforming power of the Spirit of Christ. The Spirit transforms the character of the person according to that of Christ and the Spirit transforms the church according to the qualities of equality, unity and freedom. This passage is Paul's confession and testimony to the world that the fundamental change in his own life was brought about by faith in Christ and not his doing of the works of the law.

The process of the transformation of the South African society officially started in 1994 but the discourse on it had started long before that - for example, with the contributions made by the Kairos Document and the Belhar Confession. While the latter contributed to the process of transformation in the society, it is intended to bring unity within the Dutch Reformed family. In this respect it has sadly not made significant progress. One would have expected these churches to form the vanguard of the process of transformation. Sadly, they seem to play exactly the opposite role.

\section{BiBLIOGRAPHY}

Cloete, G. D. and Smit, D. J. (Eds). 1984. A Moment of Truth. Grand Rapids, MI: Eerdmans.

Cullmann, O. 1949. The Earliest Christian Confessions. London: Lutterworth.

Beker, J. C. 1980. Paul The Apostle. The Triumph of God in Life and Thought. Philadephia, PA: Fortress.

Betz, H. 1979. Galatians. A Commentary on Paul's Letter to the Churches in Galatia. Philadephia, PA: Fortress. Bruce, F. F. 1982. The Epistle to the Galatians. A Commentary on the Greek Text. New International Greek Testament Commentary. Exeter: Pateroster.

Dunn, J. D. G. 1993. The Theology of Paul's Letter to the Galatians. New Testament Theology. Cambridge: Cambridge University Press.

Grossouw, W. 1974. De Brief van Paulus aan de Galaten. (The Epistle of Paul to the Galatians) Het Nieuwe Testament. Bussum: Romen of Galatians 3.1 - 4.11. (SBLDS 56). Chicago, IL: Scholars.

Hays, R. B. 1983. The Faith of Jesus Christ. An Investigation of the Narrative Substructure of Galatians 3:14:11, SBLDS 56, Chicago, IL: Scholars.

Morris, L. 1996, Galatians. Paul's Charter for Christian Freedom. Downers Grove, IL: Intervarsity Press. 
NGTT: Oopbron - http://ngtt.journals.ac.za

Neufeld, V. H. 1963. The Earliest Christian Confessions. Grand Rapids, MI: Eerdmans. Neyrey, J. H. 1990. Paul, In Other Words. A Cultural Reading of his Letter. Louisville, KY: Westminster John Knox.

Patte, D. 1983. Paul's Faith and the Power of the Gospel. Philadephia, PA: Fortress.

\section{KEY WORDS}

Galatians 2:15-21

Confession of Belhar

Justification by Faith

Transformation

Church Unity

\section{TREFWOORDE}

Galasiërs 2:15-21

Belydenis van Belhar

Regverdiging deur die geloofs

Transformasie

Kerkeenheid

Contact Details/Kontakbesonderhede

Prof. G Daan Cloete

Professor Emeritus

New Testament

Department of Religion and Theology

University of the Western Cape

South Africa

gcloete@uwc.ac.za 